УДК 631.155

\title{
DAIRY INDUSTRY IN UKRAINE: EVALUATION OF BUSINESS EFFICIENCY
}

G. Penchuk

National University of Food Technologies

\begin{tabular}{l}
$\quad$ Key words: \\
Dairy industry of Ukraine \\
Performance \\
Effectiveness \\
Efficiency \\
Synergistic effect \\
\hline
\end{tabular}

Article history:

Received 06.03.2018

Received in revised form

30.03.2018

Accepted 12.04.2018

Corresponding author:

G. Penchuk

E-mail:

npnuht@ukr.net

\begin{abstract}
The paper considers the problem of maintaining priority development of milk processing plants, emphasizing great importance of the formation of evaluation system. The overview of scientific approaches to the definition of the operation of enterprises is done. The establishment of the relationship between the concepts of "efficiency" and "effectiveness" is established, their common and distinctive features are highlighted, and it is proposed to consider the effectiveness of the functioning of enterprises as the achievement of the final result of its financial and economic activity, which is somewhat different, in contrast to the classical concept of "function management" or "functioning of the economic system". The importance of the distinction between the effectiveness and efficiency is substantiated. The financial-economic diagnostics and dynamics of performance indexes of functioning of dairy industry enterprises with the use of multiplicative modeling and calculations by the integral factor analysis method have been carried out. The priority directions of solving the problems of evaluating the performance indicators of the operation of enterprises in general is the construction of a methodology that substantiates the strategy of the enterprise in the current perspective in the context of business processes from the standpoint of efficiency and effectiveness of its activities. The practical implementation of the methodology should be implemented as a system of economic methods of measurement, analysis, planning within the organizational forms and processes of their functioning. The evaluation of performance on key indicators is developed regarding the main activities of milk processing enterprises in Ukraine, requirements and standards. The areas of company's management are identified to operate successfully under the market conditions.
\end{abstract}

DOI: $10.24263 / 2225-2924-2018-24-2-11$

\section{ОЦІНКА РЕЗУЛЬТАТИВНОСТІ ДІЯЛЬНОСТІ ПІДПРИЕМСТВ МОЛОЧНОЇ ГАЛУЗІ УКРАЇНИ}

\author{
Г.С. Пенчук
}

Національний університет харчових технологій

У статті розглянуто проблему забезпечення пріоритетного розвитку молокопереробних підприємств, серед яких велике значення надається фор- 
муванню системи оцуіни результативності. Узагальнено наукові підходи до визначення поняття результативності функціонування підприємств. Встановлено взаємозв 'язок між поняттями «ефективність» $i$ «результативність», виділено їхні спільні та відмінні риси, а також запропоновано розглядати результативність функціонування підприємств, як досягнення кінцевого результату його фінансово-господарської діяльності, щзо дещзо інше на відміну від класичного поняття «функиї господарювання» або "функиіонування господарської системи». Обгрунтовано важливість розмежування понять ефективності від результативності. Проведена фінансово-економічна діагностика та динаміка показників результативності функціонування підприємств молокопереробної промисловості із застосуванням мультиплікативного моделювання та здійснення розрахунків інтегральним методом факторного аналізу.

Пріоритетними напрямами вирішення проблем оцінки показників результативності функціонування підприємств в иүілому є побудова методологї, щуо обтрунтовує стратегію підприємства в поточній перспективі в розрізі бізнес-прочесів з позицій ефективності $i$ результативності його діяльності. Практична реалізація методологї має бути здійснена як система економічних методів виміру, аналізу, планування в рамках організаційних форм і прочесів їх функиіонування.

Проведено очінку результативності за ключовими показниками, розробленими з урахуванням основних видів діяльності молокопереробних підприємств Украӥни, вимог і стандартів. Визначено ділянки, управління якими дасть змогу підприємству успішно функиіонувати в умовах ринку.

Ключові слова: молочна промисловість Украӥни, продуктивність, ефективність, результативність, синергічний ефект.

Постановка проблеми. Перехід економіки України на ринкові відносини призвів до значних змін у діяльності підприємств в цілому. Значні темпи розвитку економіки, динаміка зовнішнього та внутрішнього середовища вимагає від підприємства трансформації на обох цих рівнях. Криза української економіки, що торкнулася всіх галузей народного господарства, не оминула і молочну промисловість. Молочна галузь займає важливе місце в економіці будь-якої держави та забезпеченні населення продуктами харчування першої необхідності. Молоко та молочні продукти містять практично всі речовини, необхідні організму. Вони мають важливе значення як для забезпечення здоров'я населення та збалансування харчового раціону, так i для продовольчого ринку. 3 огляду на це молоко та молочні продукти є одними 3 основних продуктів споживання в раціоні населення України та продуктом соціального значення [1].

Отже, функціонування молокопереробних підприємств у сучасних умовах економічного розвитку потребує більш глибокого реформування, підвищення його ефективності та результативності.

Необхідно звернути увагу на те, що в економічній літературі вивчення показника ефективності широко розглянуто як на теоретичному, так i на 
практичному рівні. Але в сучасних умовах, на нашу думку, доцільніше розглянути інший, не менш важливий показник успішного функціонування підприємства - його результативність. Цей показник дає змогу досягти високого динамізму економічного зростання. Оцінювання результативності роботи підприємства є одним з основних елементів системи управління та обгрунтування господарських рішень. Досвід функціонування найбільш успішних підприємств у ринкових відносинах показав, що для успішної роботи будь-якого підприємства важливою $є$ постановка правильних цілей та їх виконання з найменшими затратами ресурсів.

Аналіз останніх досліджень і публікацій. Теоретичні й практичні дослідження оцінки результативності діяльності підприємства висвітлені в працях вітчизняних і зарубіжних вчених: В. Паретто, Е. Барона, П. Друкера, Ф. Хайєка, М. Алле, К. Куросави, А. Лоурола, Д. Скотт Сінка, Д. Нортона, Т. Пітерса, Р. Уотермана, Ю. Шрейдера, Т. Хачатурова, С. Ейлона, Б. Голда, Ю. Сьозана, С. Покропивного, В. Гейця, І. Прокопенка, А. Матлина, А. Барсова, В. Московича, В. Батрасова, А. Сильченкова, В. Прядка, В. Хрипача, А. Борисова, Р. Пєтухова, О.І. Олексюка, А.Н. Тищенко та інших.

Деякі теоретичні та науково-практичні проблеми, пов'язані 3 результативністю функціонування підприємств і заходів щодо іiі підвищення, не отримали до теперішнього часу належної наукової розробки й узагальнення. Враховуючи сказане, виникає необхідність у подальшому поглибленні теоретичних і методичних положень розробки оцінки та алгоритму підвищення результативності функціонування підприємств, що забезпечить можливість оцінити зміни в діяльності підприємств, визначити міру реалізації запланованих завдань і досягнення результатів, вибрати найбільш раціональний спосіб вдосконалення їх діяльності.

Метою статті є дослідження та проведення оцінки діяльності підприємств молочної галузі України.

Виклад основних результатів дослідження. Сьогодні в Україні рівень наукових досліджень поняття «результативності», на жаль, відстає від зарубіжних розробок, оскільки цей термін дуже часто ототожнюють 3 поняттям ефективності. На нашу думку, це важлива й актуальна проблема сьогодення. Слід відзначити, що, незважаючи на підвищену увагу до проблеми визначення й оцінки результативності та ефективності на всіх рівнях народного господарства, в економічній літературі немає чіткого трактування сутності цих понять. Змішуються поняття результату й результативності, ефективності й ефекту а також результативності й ефективності. Починаючи з 80-90-х років XX ст. ситуація змінюється кардинальним чином, і в спеціалізованих наукових публікаціях дослідники віддають перевагу використанню терміну «результативність» [2].

На нашу думку, результативність діяльності підприємства - це економічна категорія, яка включає в себе сукупність взаємопов'язаних показників, що характеризують підприємство з позиції правильності поставлених завдань i раціонального використання ресурсів. Під правильністю поставлених завдань слід розуміти результати, які задовольнять потреби власників, їх підлеглих і споживачів. Отже, в нашому розумінні ефективність є складовою части- 
ною результативності. Ефективність - це поняття, яке передбачає порівняння отриманих результатів діяльності 3 величиною витрачених ресурсів, виступає співвідношенням між ресурсами та результатами економічної діяльності і має технічний характер. Підприємство може бути ефективним, але не результативним. Таке твердження підкреслює важливість розмежування цих понять.

3 метою акцентування уваги саме на проблематиці оцінки ефективності та результативності нами проведений агрегований аналіз на основі фінансової звітності п'яти підприємств молокопереробної промисловості.

Представлені нижче розрахунки базуються на методиці Р.М. Пєтухова, яка передбачає оцінку ефективності промислового виробництва, а саме: технологію індексних розрахунків. Окремої уваги заслуговує трактування двох основних аналітичних індикаторів - показника ефективності виробництва та співвідношення рівня ефективності та динаміки витрат (так званий $d$-коефiцієнт). Тож у табл. 1 представлені розрахунки за чистим доходом від реалізації продукції.

Таблиия 1. Індекси ефективності розвитку підприємств молокопереробної промисловості, 2012-2016 pp.

\begin{tabular}{|c|c|c|c|c|c|}
\hline Підприємства & $2013 / 2012$ & $2014 / 2013$ & $2016 / 2015$ & Середнє & Вид індексу \\
\hline \multirow{4}{*}{$\begin{array}{c}\text { ПАТ «Кременчуцький } \\
\text { міськмолокозавод» }\end{array}$} & 0,87 & 1,29 & 1,18 & 1,12 & реалізація \\
\hline & 0,95 & 1,22 & 1,08 & 1,08 & собівартість \\
\hline & 0,92 & 1,06 & 1,09 & 1,04 & ефективність \\
\hline & 0,97 & 0,87 & 1 & 0,96 & $d$ koef \\
\hline \multirow{4}{*}{ ПАТ «Ковельмолоко» } & 0,76 & 0,74 & 0,67 & 0,72 & реалізація \\
\hline & 0,69 & 0,65 & 0,78 & 0,71 & собівартість \\
\hline & 1,1 & 1,12 & 0,86 & 1,02 & ефективність \\
\hline & 1,6 & 1,7 & 1,1 & 1,44 & $d$ koef \\
\hline \multirow{4}{*}{$\begin{array}{c}\text { ПАТ «Христинівський } \\
\text { молокозавод» }\end{array}$} & 1,09 & 0,65 & 2,86 & 1,53 & реалізація \\
\hline & 1,07 & 0,6 & 2,9 & 1,52 & собівартість \\
\hline & 1,02 & 1,08 & 0,98 & 1 & ефективність \\
\hline & 0,95 & 1,8 & 0,34 & 0,66 & $d$ koef \\
\hline \multirow{4}{*}{$\begin{array}{c}\text { ПАТ «Нововодолазький } \\
\text { молокозавод» }\end{array}$} & 0,79 & 2,11 & 1,27 & 1,39 & реалізація \\
\hline & 0,74 & 2,16 & 1,36 & 1,42 & собівартість \\
\hline & 1,07 & 0,98 & 0,93 & 0,98 & ефективність \\
\hline & 1,45 & 0,45 & 0,68 & 0,69 & $d$ koef \\
\hline \multirow{4}{*}{ ТДВ «Бровари-молоко» } & 1,07 & 1,1 & 1,05 & 1,07 & реалізація \\
\hline & 1,09 & 1,16 & 1,08 & 1,11 & собівартість \\
\hline & 0,98 & 0,95 & 0,97 & 0,96 & ефективність \\
\hline & 0,9 & 0,82 & 0,9 & 0,86 & $d$ koef \\
\hline
\end{tabular}

3 наведених у табл. 1 даних можна зробити висновок, що підприємство ПАТ «Нововодолазький молокозавод» і ТДВ «Бровари-молоко» розвиваються за екстенсивним (регресивним) сценарієм. У вказаних підприємств індекс коефіцієнта ефективності та $d$-коефіцієнта менший за одиницю, що свідчить про «проїдання» потенціалу та неефективне використання економічних ресурсів. У таких підприємствах, як ПАТ «Христинівський молокозавод» $\mathrm{i}$ 
ПАТ «Кременчуцьький міськмолокозавод» розвиток також характеризується регресивністю, оскільки $d$-коефіцієнт менший за 1 , але ресурси використовуються ефективно. Цим підприємствам рекомендовано змінити політику витрат. Що стосується ПАТ «Ковельмолоко», це підприємство розвивається за регресивною моделлю, оскільки індекс ефективності та $d$-коефіцієнт більший за 1. Слід також відзначити, що фактично всі підприємства нашої вибірки мають значення $d$-коефіцієнта менше за одиницю. Така ситуація свідчить про певну нераціональність сформованих моделей розвитку з позицій донесення вартості молочної продукції до ії кінцевих споживачів

Методика оцінки результативності. Забезпечення пріоритетного розвитку молокопереробних підприємств вимагає вирішення комплексу проблем, серед яких велике значення надається вдосконаленню фінансово-економічних механізмів, покликаних забезпечити прозорість фінансування, зростання економічної самостійності, інвестиційної привабливості і відповідальності підприємств за результати діяльності.

Для діагностики результативності має бути розроблена методика оцінки на основі критеріїв, щоб відмітити зміни, що сталися, в діяльності підприємства, визначити міру реалізації запланованих завдань і досягнення запланованих результатів, вибрати найбільш раціональний спосіб вдосконалення діяльності. Оцінка результативності повинна здійснюватися за ключовими показниками.

Складність проблеми аналізу оцінки результативності пов'язана 3 їх багатоаспектністю, тому необхідно визначити ділянки, управління якими дасть змогу підприємству успішно функціонувати в умовах ринку.

Відстоюючи точку зору щодо включення показника ефективності до теорії результативності, нами була використана одна 3 найпоширеніших методик оцінки управління результативності - технологія аналізу Д. Скотт-Сінка [3]. Слід зазначити, що авторські розрахунки дещо змінені відповідно до цілей аналізу та інформаційних можливостей (рис.).

Управління результативністю ми розглядаємо як процес вибору, аналізу та вимірювання системи взаємопов'язаних показників для досягнення результативного функціонування підприємства.

Діагностика результативності. Логічним кроком нашого дослідження $\epsilon$ розрахунок представлених показників за кожним підприємством вибірки.

Отже, першим кроком розрахунку результативності $\epsilon$ визначення показника дієвості діяльності підприємств вибірки за 2013-2016 роки.

Слід відзначити, що запланований приріст обсягів реалізації продукції визначається на середньогалузевому рівні, тобто окреме підприємство повинне збільшити обсяг реалізації за визначений період хоча б пропорційно зростанню місткості молочного ринку (табл. 2). Такі міркування побудовані на логіці збереження ринкової позиції, тобто у протилежному випадку слід очікувати зменшення ринкової частки підприємства:

Місткість ринку = Чистий дохід від реалізації продукції +

$$
\text { + Імпорт-Експорт. }
$$




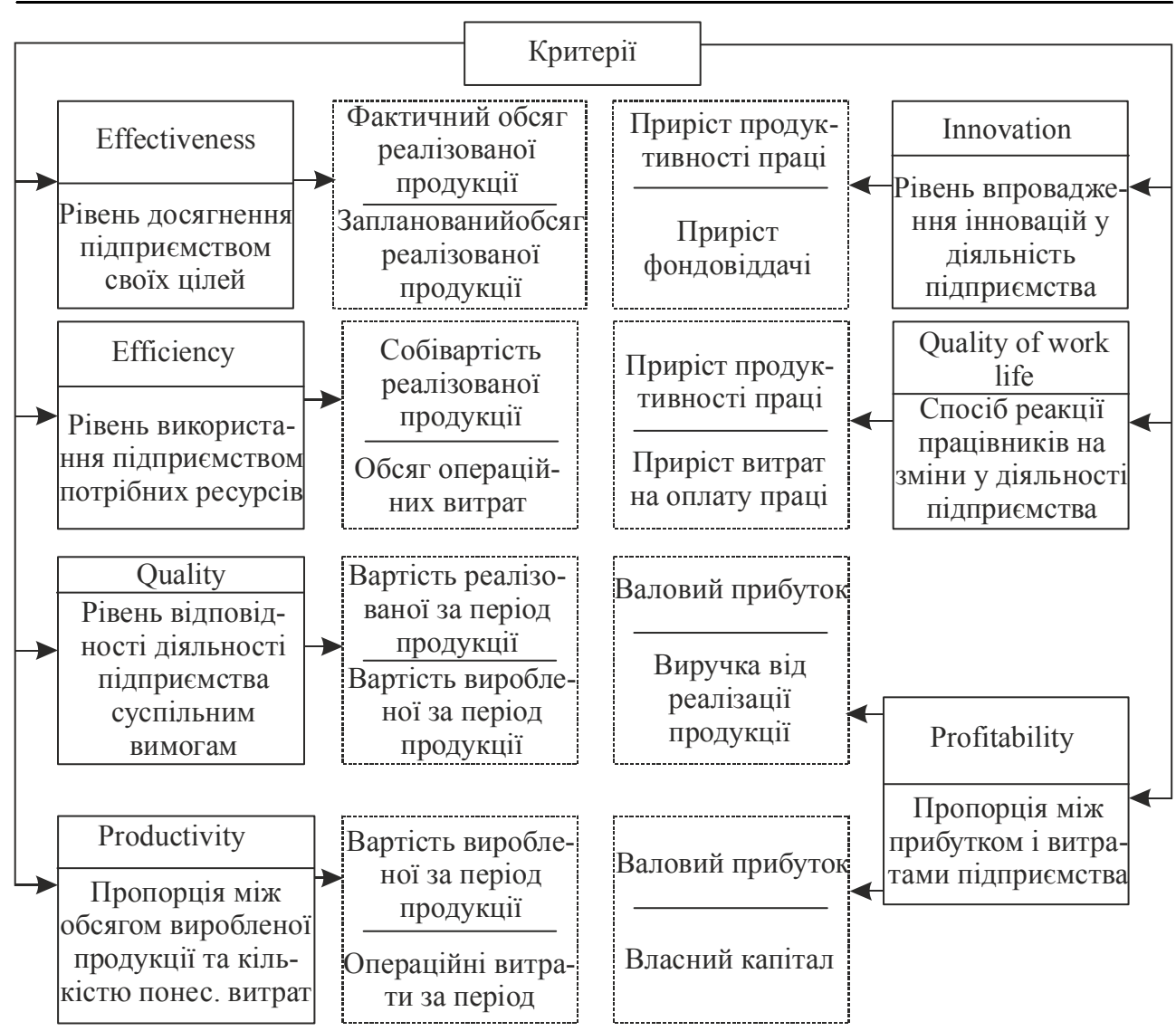

\section{Рис. Логіка синтезу показника результативності на основі моделі Д. Скотт-Сінка}

Табличя 2. Розрахунок місткості ринку молока та молочних продуктів України y $2013-2016$ pp.

\begin{tabular}{|c|c|c|c|c|}
\hline Показники & 2013 & 2014 & 2015 & 2016 \\
\hline $\begin{array}{c}\text { Чистий дохід від реалізації продукції } \\
\text { молокопереробних підприємств, млн грн }\end{array}$ & 16500,2 & 16753,8 & 20420,3 & 23740,5 \\
\hline Імпорт, млн грн & 889,7 & 896,74 & 904,68 & 1097,88 \\
\hline Експорт, млн грн & 5778,4 & 3388,6 & 4652,4 & 5195,04 \\
\hline $\begin{array}{c}\text { Місткість ринку молочних продуктів } \\
\text { України, млн грн }\end{array}$ & 11611,5 & 14261,94 & 16672,58 & 19643,34 \\
\hline
\end{tabular}

3 даних, наведених в табл. 2, визначаємо показник дієвості, який характеризує рівень виконання підприємством поставлених цілей:

$$
\text { Дієвість }=\frac{\text { Індекс зростання чистого доходу від реалізації продукції }}{\text { Індекс місткості ринку }} .
$$

Покращення ринкових позицій і перевищення індексу дієвості одиниці протягом 2013-2016 рр. спостерігається у таких підприємствах, як ПАТ 
«Кременчуцький міськмолокозавод», ПАТ «Нововодолазький молокозавод» та у 2015 рр. ПАТ «Христинівський молокозавод». Щодо діяльності інших підприємств, то йдеться про їх певне відставання від динаміки зростання ринку молока та молочних продуктів.

Таблиия 3. Розрахунок показника дієвості за 2013-2016 pp.

\begin{tabular}{|c|c|c|c|c|c|c|}
\hline \multirow{2}{*}{ Підприємства } & \multicolumn{2}{|c|}{$\begin{array}{c}\text { Індекси зростання обсягів } \\
\text { реалізованої продукції } \\
\text { (за чистим доходом від реалізації) }\end{array}$} & \multicolumn{3}{|c|}{ Індекс дієвості } \\
\cline { 2 - 7 } & $2012 / 2011$ & $2014 / 2013$ & $2016 / 2015$ & $2013 / 2012$ & $2014 / 2013$ & $2016 / 2015$ \\
\hline $\begin{array}{c}\text { ПАТ «Кременчуцький } \\
\text { міськмолокозавод» }\end{array}$ & 0,87 & 1,29 & 1,18 & 0,7 & 1,1 & 1,0 \\
\hline ПАТ «Ковельмолоко» & 0,76 & 0,74 & 0,67 & 0,62 & 0,63 & 0,57 \\
\hline $\begin{array}{c}\text { ПАТ «Христинівський } \\
\text { молокозавод» }\end{array}$ & 1,07 & 0,6 & 2,9 & 0,87 & 0,51 & 2,46 \\
\hline $\begin{array}{c}\text { ПАТ «Нововодолазький } \\
\text { молокозавод» }\end{array}$ & 0,79 & 2,11 & 1,27 & 0,64 & 1,8 & 1,08 \\
\hline ТДВ «Бровари-молоко» & 1,07 & 1,1 & 1,05 & 0,9 & 0,94 & 0,89 \\
\hline $\begin{array}{c}\text { Місткість ринку молока } \\
\text { та молокопродуктів }\end{array}$ & 1,23 & 1,17 & 1,18 & - & - & - \\
\hline
\end{tabular}

Наступним кроком нашого дослідження є визначення показника економічності діяльності підприємств за 2013-2016 роки.

У розрахунках використовуються два основних витратних показники господарської діяльності, які виділяються у фінансово-статистичній звітності підприємств: собівартість реалізованої продукції та операційні витрати. Вибір першого показника продиктований його інформаційною доступністю i зв'язком з ринком. Собівартість проданої продукції відображає ресурси, продані підприємством споживачам їх продукції, тобто відображає обсяг використання затребуваних ринком ресурсів. Сума ж операційних витрат за своєю суттю характеризує обсяги витрат підприємств за певний період. Тобто скільки підприємство споживало економічних ресурсів за різні періоди свого розвитку. Вважаємо, що зіставлення цих двох економічних показників має певний сенс з позицій оцінки результативності.

Якщо собівартість реалізованої продукції менша, ніж валові витрати за той же період, слід вважати, що підприємство споживає більше ресурсів, ніж продає (чи списує) на ринку. Значення показника економічності при цьому менше одиниці. У випадку, коли значення економічності більше за одиницю, слід говорити про перевищення вартості проданих на ринку економічних ресурсів над обсягами спожитих ресурсів за той же період (така ситуація можлива при врахуванні складських запасів, витрат майбутніх періодів тощо):

$$
\text { Економічність }=\frac{\text { Собівартість реалізованої продукції }}{\text { Операційні витрати за період }} \text {. }
$$

У всіх підприємств значення показника економічності менше за одиницю, що свідчить про споживання частини економічних ресурсів без їх подальшого збуту споживачам у структурі собівартості продукції. Але слід відмітити, що розрив 


\section{ЕКОНОМІКА І СОЦІАЛЬНИЙ РОЗВИТОК}

між проданими і спожитими ресурсами невеликий, більшість показників економічності наближені до одиниці. Найкраща ситуація у таких підприємств, як ТДВ «Бровари-молоко» та ПАТ «Кременчутський міськсолокозавод».

Таблиия 4. Розрахунок показника економічності за 2013-2016 pp.

\begin{tabular}{|c|c|c|c|}
\hline Рік & $\begin{array}{c}\text { Собівартість реалізованої } \\
\text { продукції, тис. грн }\end{array}$ & $\begin{array}{c}\text { Операційні витрати за } \\
\text { період, тис. грн }\end{array}$ & Економічність \\
\hline \multicolumn{4}{|c|}{ ПАТ «Кременчуцький міськмолокозавод» } \\
\hline 2013 & 217353 & 215006 & 1,01 \\
\hline 2014 & 205924 & 214461 & 0,96 \\
\hline 2015 & 250443 & 267322 & 0,93 \\
\hline 2016 & 270600 & 302446 & 0,89 \\
\hline \multicolumn{4}{|c|}{ ПАТ «Ковельмолоко» } \\
\hline 2013 & 273677 & 293450 & 0,93 \\
\hline 2014 & 187735 & 202054 & 0,93 \\
\hline 2015 & 122596 & 168501 & 0,73 \\
\hline 2016 & 95397 & 155397 & 0,61 \\
\hline \multicolumn{4}{|c|}{ ПАТ «Христинівський молокозавод» } \\
\hline 2013 & 71060 & 99268 & 0,72 \\
\hline 2014 & 76244 & 87952 & 0,87 \\
\hline 2015 & 45582 & 69658 & 0,65 \\
\hline 2016 & 131375 & 144658 & 0,91 \\
\hline \multicolumn{4}{|c|}{ ПАТ «Нововодолазький молокозавод» } \\
\hline 2013 & 9535 & 10326 & 0,92 \\
\hline 2014 & 7033 & 8114 & 0,87 \\
\hline 2015 & 15164 & 15879 & 0,95 \\
\hline 2016 & 20584 & 23507 & 0,88 \\
\hline \multicolumn{4}{|c|}{ ТДВ «Бровари-молоко» } \\
\hline 2013 & 6036 & 6734 & 0,9 \\
\hline 2014 & 6580 & 7203 & 0,91 \\
\hline 2015 & 7614 & 8318 & 0,92 \\
\hline 2016 & 8239 & 8708 & 0,95 \\
\hline
\end{tabular}

Далі розраховуємо рівень якості планування продукції відібраних нами п'яти підприємств. Ми охарактеризуємо здатність задовольняти потреби замовника за рахунок здійснення основної діяльності згідно встановлених вимог:

$$
\text { Якість планування }=\frac{\text { Вартість реалізованої за період продукції }}{\text { Вартість виробленої за період продукції }}
$$

Таблиия 5. Розрахунок показника якості за 2013-2016 pp.

\begin{tabular}{|c|c|c|c|}
\hline Рік & $\begin{array}{c}\text { Вартість реалізованої за } \\
\text { період продукції, } \\
\text { тис. грн }\end{array}$ & $\begin{array}{c}\text { Вартість виробленої за } \\
\text { період продукції, } \\
\text { тис. грн }\end{array}$ & Якість планування \\
\hline 1 & 2 & 3 & 4 \\
\hline \multicolumn{4}{|c|}{ ПАТ «Кременчуцький міськмолокозавод» } \\
\hline 2013 & 84145 & 84007 & 1 \\
\hline 2014 & 97269 & 85053,5 & 1,14 \\
\hline 2015 & 153533,9 & 109042 & 1,4 \\
\hline
\end{tabular}


ENTERPRISE ECONOMY AND SOCIAL DEVELOPMENT

\begin{tabular}{|c|c|c|c|}
\hline \multicolumn{4}{|c|}{ Продовження табл. 5} \\
\hline 1 & 2 & 3 & 4 \\
\hline 2016 & 321361,49 & 255184,95 & 1,26 \\
\hline \multicolumn{4}{|c|}{ ПАТ «Ковельмолоко» } \\
\hline 2013 & 220346 & 227103 & 0,97 \\
\hline 2014 & 216874 & 204230 & 1,06 \\
\hline 2015 & 128704 & 135643 & 0,9 \\
\hline 2016 & 67918 & 66164 & 1,02 \\
\hline \multicolumn{4}{|c|}{ ПАТ «Христинівський молокозавод» } \\
\hline 2013 & 93200,4 & 93158,2 & 1 \\
\hline 2014 & 97993,9 & 82213,4 & 1,19 \\
\hline 2015 & 57899,24 & 53370,6 & 1,08 \\
\hline 2016 & 119785,32 & 119763,6 & 1 \\
\hline \multicolumn{4}{|c|}{ ПАТ «Нововодолазький молокозавод» } \\
\hline 2013 & 7450 & 7327 & 1,02 \\
\hline 2014 & 7015 & 7015 & 1 \\
\hline 2015 & 12675,5 & 12727,3 & 0,9 \\
\hline 2016 & 16202,1 & 16121,26 & 1,01 \\
\hline \multicolumn{4}{|c|}{ ТДВ «Бровари-молоко» } \\
\hline 2013 & 6890 & 6100 & 1,13 \\
\hline 2014 & 6010 & 5095 & 1,18 \\
\hline 2015 & 7808 & 7003,5 & 1,1 \\
\hline 2016 & 9810 & 8364 & 1,2 \\
\hline
\end{tabular}

Отже, обсяг реалізованої продукції визначається продажною вартістю відвантаженої продукції, зазначеною в оформлених для сплати розрахункових документах, не залежить від фактичного надходження грошової виручки. Реалізація продукції - це ланка зв'язку між виробником і споживачем.

Слід підкреслити, що всі без винятку підприємства вибірки показали позитивний показник якості (більше 1). Це свідчить про те, що вони продають свою продукцію дорожче за витрати, понесені на виробництво, їхня продукція користується попитом. Отже, всі підприємства випускають якісну та конкурентоспроможну продукцію.

Наступним етапом аналізу стало визначення продуктивності праці - показника, який відображає результативність та ефективність праці людини [4]. Показник продуктивності праці розраховуватимемо згідно 3 моделлю Д. Скотт-Сінка, який під продуктивністю розуміє кількість виробленої продукції на одиницю використаних економічних ресурсів:

$$
\text { Продуктивність }=\frac{\text { Вартість виробленої за період продукції }}{\text { Операційні витрати за період }} \text {. }
$$

Таблиия 6. Розрахунок показника продуктивності за 2013-2016 pp.

\begin{tabular}{|c|c|c|c|}
\hline Рік & $\begin{array}{c}\text { Вартість виробленої } \\
\text { за період продукції, } \\
\text { тис. грн }\end{array}$ & $\begin{array}{c}\text { Операційні витрати за } \\
\text { період, тис. грн }\end{array}$ & Продуктивність \\
\hline 1 & 2 & 3 & 4 \\
\hline \multicolumn{4}{|c|}{ ПАТ «Кременчуцький міськмолокозавод» } \\
\hline 2013 & 190367 & 215006 & 0,88 \\
\hline
\end{tabular}




\begin{tabular}{|c|c|c|c|}
\hline \multicolumn{4}{|c|}{ Продовження табл. 6} \\
\hline 1 & 2 & 3 & 4 \\
\hline 2014 & 159844,95 & 214461 & 0,74 \\
\hline 2015 & 197182,64 & 267322 & 0,73 \\
\hline 2016 & 280423,02 & 302446 & 0,92 \\
\hline \multicolumn{4}{|c|}{ ПАТ «Ковельмолоко» } \\
\hline 2013 & 227103 & 293450 & 0,77 \\
\hline 2014 & 204230 & 202054 & 1,01 \\
\hline 2015 & 135643 & 168501 & 0,8 \\
\hline 2016 & 66164 & 155397 & 0,43 \\
\hline \multicolumn{4}{|c|}{ ПАТ «Христинівський молокозавод» } \\
\hline 2013 & 93158,2 & 99268 & 0,94 \\
\hline 2014 & 82213,4 & 87952 & 0,93 \\
\hline 2015 & 53370,6 & 69658 & 0,8 \\
\hline 2016 & 119763,6 & 144658 & 0,83 \\
\hline \multicolumn{4}{|c|}{ ПАТ «Нововодолазький молокозавод» } \\
\hline 2013 & 7327 & 10326 & 0,71 \\
\hline 2014 & 7015 & 8114 & 0,86 \\
\hline 2015 & 12727,3 & 15879 & 0,8 \\
\hline 2016 & 16121,26 & 23507 & 0,7 \\
\hline \multicolumn{4}{|c|}{ ТДВ «Бровари-молоко» } \\
\hline 2013 & 6100 & 6734 & 0,9 \\
\hline 2014 & 5095 & 7203 & 0,7 \\
\hline 2015 & 7003,5 & 8318 & 0,84 \\
\hline 2016 & 8364 & 8708 & 0,96 \\
\hline
\end{tabular}

Розрахована продуктивність за операційними витратами підтверджує, що всі підприємства вибірки нераціонально використовують ресурси.

Наступним кроком визначення результативності п'яти підприємств молокопереробної промисловості $€$ розрахунок показника інноваційної діяльності. В сучасних умовах розвитку економіки важливим чинником забезпечення ефективного довгострокового функціонування підприємств $\epsilon$ успішне здійснення інноваційної діяльності. Система управління інноваційною діяльністю підприємства має багатогранний характер, втілюючи у собі єдність технологічних, організаційних і соціальних інструментів, що суттєво ускладнює економічні розрахунки [5].

У табл. 7 визначався показник інноваційної діяльності підприємства на основі зіставлення змін двох показників - продуктивності праці (за чисельністю персоналу) та фондовіддачі. Перший з них відображає рівень ефективності використання людини як носія й активного чинника соціально-економічної системи підприємства. На рівень продуктивності праці за той чи інший період справляють вплив декілька основних груп факторів - матеріально-технічні, організаційні та соціально-психологічні. Стосовно показника фондовіддачі слід відзначити, що він відображає рівень прогресивності технології виробництва. У випадку, коли рівень продуктивності праці зростає більш швидшими темпами, ніж фондовіддача в окремого підприємства за той же період, йдеться про використання саме організаційних і соціально-психологічних факторів ії зростання (технічні чинники відстають). 


$$
\text { Інноваційність }=\frac{\text { Індекс продуктивності праці }}{\text { Індекс фондовіддачі }}
$$

Продуктивність праці $=\frac{\text { Чистий дохід від реалізації продукції }}{\text { Середньооблікова чисельність персоналу }}$.

$$
\text { Фондовіддача }=\frac{\text { Вартість виробленої продукції }}{\text { Середньорічна вартість основних засобів }} \text {. }
$$

\begin{tabular}{|c|c|c|c|}
\hline Рік & $\begin{array}{c}\text { Індекс змін } \\
\text { продуктивності праці }\end{array}$ & $\begin{array}{c}\text { Індекс змін } \\
\text { фондовіддачі }\end{array}$ & Інноваційність \\
\hline \multicolumn{4}{|c|}{ ПАТ «Кременчуцький міськмолокозавод» } \\
\hline $2014 / 2013$ & 1,24 & 1,01 & 1,23 \\
\hline $2015 / 2014$ & 1,31 & 1,4 & 0,94 \\
\hline $2016 / 2015$ & 1,23 & 1,01 & 1,22 \\
\hline \multicolumn{4}{|c|}{ ПАТ «Ковельмолоко» } \\
\hline $2014 / 2013$ & 0,76 & 0,7 & 1,08 \\
\hline $2015 / 2014$ & 0,66 & 0,75 & 0,88 \\
\hline $2016 / 2015$ & 0,9 & 0,7 & 1,29 \\
\hline \multicolumn{4}{|c|}{ ПАТ «Христинівський молокозавод» } \\
\hline $2014 / 2013$ & 1,36 & 0,76 & 1,8 \\
\hline $2015 / 2014$ & 0,64 & 0,54 & 1,19 \\
\hline $2016 / 2015$ & 2,79 & 0,93 & 3 \\
\hline \multicolumn{4}{|c|}{ ПАТ «Нововодолазький молокозавод» } \\
\hline $2014 / 2013$ & 0,87 & 0,71 & 1,23 \\
\hline $2015 / 2014$ & 1,02 & 1,83 & 0,56 \\
\hline $2016 / 2015$ & 1,3 & 1,44 & 0,9 \\
\hline \multicolumn{4}{|c|}{ ТДВ «Бровари-молоко» } \\
\hline $2014 / 2013$ & 1,15 & 0,99 & 1,16 \\
\hline $2015 / 2014$ & 1,37 & 1 & 1,37 \\
\hline $2016 / 2015$ & 1,05 & 0,95 & 1,1 \\
\hline
\end{tabular}

Таблиия 7. Розрахунок показника інноваційності за 2013-2016 pp.

Слід зазначити, що більшість підприємств вибірки орієнтуються саме на використання організаційних і соціально-психологічних чинників підвищення ефективності їх діяльності та йде шляхом мінімізації інвестиційних витрат і досягнення зростання ефективності їх діяльності на основі саме організаційних і мотиваційних факторів роботи персоналу, оскільки значення індексу інноваційності у них за 2013-2016 рр. в основному перевищує одиницю. Тільки ПАТ «Нововодолазький молокозавод» за 2015-2016 рр. значно покращив свої технічні чинники, про що свідчить перевищення темпів зміни фондовіддачі від темпів зміни продуктивності праці.

Наступним кроком аналізу результативності стане розрахунок показника якості трудового життя.

Якість трудового життя характеризує здатність задовольняти потребу працівників стосовно умов праці. Це величина, яка відображає відповідність умов праці, що склалися, потребам працівників [6]. 
Для розрахунку даного показника робиться припущення, що при підвищенні продуктивності праці більш високими темпами, ніж зростає за цей же період фонд оплати праці, слід говорити про підвищення якості трудового життя працівників підприємств вибірки. Хоча відзначимо, що використана методика та припущення при визначенні якості трудового життя, не дає можливість зробити однозначні висновки, але найкраще характеризує цю складну соціально-економічну характеристику трудового колективу підприємства:

$$
\text { Якість трудового життя }=\frac{\text { Індекс продуктивності праці }}{\text { Індекс витрат на оплату праці }}
$$

Таблиия 8. Розрахунок показника якості трудового життя за 2013-2016 рр.

\begin{tabular}{|c|c|c|c|}
\hline Рік & $\begin{array}{c}\text { Індекс продуктивності } \\
\text { праці }\end{array}$ & $\begin{array}{c}\text { Індекс витрат на } \\
\text { оплату праці }\end{array}$ & $\begin{array}{c}\text { Якість трудового } \\
\text { життя }\end{array}$ \\
\hline \multicolumn{3}{|c|}{ ПАТ «Кременчуцький міськолокозавод» } \\
\hline $2014 / 2013$ & 1,24 & 0,84 & 1,48 \\
\hline $2015 / 2014$ & 1,31 & 1,05 & 1,25 \\
\hline $2016 / 2015$ & 1,23 & 1,11 & 1,1 \\
\hline \multicolumn{3}{|c|}{ ПАТ «Ковельмолоко» } \\
\hline $2014 / 2013$ & 0,76 & 0,86 & 0,88 \\
\hline $2015 / 2014$ & 0,66 & 1,31 & 0,5 \\
\hline $2016 / 2015$ & 0,9 & 0,85 \\
\hline \multicolumn{4}{|c|}{ ПАТ «Христинівський молокозавод» } \\
\hline $2014 / 2013$ & 1,36 & 0,46 & 2,9 \\
\hline $2015 / 2014$ & 0,64 & 1,33 & 0,48 \\
\hline $2016 / 2015$ & 2,79 & 1,2 & 2,3 \\
\hline \multicolumn{3}{|c|}{ ПАТ «Нововодолазький молокозавод» } \\
\hline $2014 / 2013$ & 0,87 & 1,21 & 0,71 \\
\hline $2015 / 2014$ & 1,02 & 2,61 \\
\hline $2016 / 2015$ & 1,3 & 0,97 & 1,34 \\
\hline \multicolumn{4}{|c|}{ ТДВ «Бровари-молоко» } \\
\hline $2014 / 2013$ & 1,15 & 1,15 & 1 \\
\hline $2015 / 2014$ & 1,37 & 0,91 & 1,5 \\
\hline $2016 / 2015$ & 1,05 & 1,13 & 0,92 \\
\hline
\end{tabular}

Отже, у підприємств ПАТ «Кременчуцький міськмолокозавод», ПАТ «Христинівський молокозавод» та ТДВ «Бровари-молоко», за період 2013-2016 рр. розрахований нами показник більший за одиницю. Це говорить про те, що продуктивність праці персоналу цих підприємств зростає швидше, ніж витрати на оплату праці. Така ситуація $є$ позитивною і свідчить про ефективну систему мотивації та свідомість працівників.

Останнім показником оцінки результативності, яка була сформована на основі наукових розробок Д. Скотт-Сінка, є розрахунок показника прибутковості.

Прибутковість характеризує здатність підприємства в часі отримувати доходи вищі, чим понесені затрати, які необхідні для його отримання. Для розрахунку остатнього критерію результативності використаємо показник 
рентабельності. Рентабельність - відносний показник, який характеризує міру прибутковості витрат або активів [7].

Виходячи із суті поняття «результативність», доцільно розрахувати саме рентабельність продажу, оскільки цей показник дає змогу оцінити рівень прибутку на кожну гривню проданої на ринку продукції та рентабельність власного капіталу, який, у свою чергу, дає змогу оцінити рівень інвестиційної привабливості підприємств.

Коефіцієнт рентабельності продажу $=\frac{\text { Валовий прибуток }}{\text { Виручка від реалізації продукції }}$

Коефіцієнт рентабельності власного капіталу $=\frac{\text { Валовий прибуток }}{\text { Власний капітал }}$

Таблиця 9. Розрахунок показника прибутковості за 2013-2016 pp.

\begin{tabular}{|c|c|c|c|c|c|c|c|c|}
\hline \multirow{2}{*}{ Підприємства } & \multicolumn{3}{|c|}{ Коефіцієнт рентабельності } & \multicolumn{4}{c|}{ Коефіцієнт рентабельності } \\
\cline { 2 - 10 } & 2013 & 2014 & 2015 & 2016 & 2013 & 2014 & 2015 & 2016 \\
\hline $\begin{array}{c}\text { ПАТ «Кременчуцький } \\
\text { міськмолокозавод» }\end{array}$ & 0,14 & 0,06 & 0,11 & 0,19 & 1,08 & 0,28 & 0,65 & 0,81 \\
\hline ПАТ «Ковельмолоко» & 0,01 & 0,13 & 0,24 & 0,12 & 0,2 & 0,09 & 0,12 & 0,04 \\
\hline $\begin{array}{c}\text { ПАТ «Христинівський } \\
\text { молокозавод» }\end{array}$ & 0,07 & 0,08 & 0,15 & 0,15 & 0,9 & 1,03 & 1,25 & 0,7 \\
\hline $\begin{array}{c}\text { ПАТ «Нововодолазький } \\
\text { молокозавод» }\end{array}$ & 0,09 & 0,15 & 0,13 & 0,07 & 0,35 & 0,5 & 0,48 & $-1,09$ \\
\hline ТДВ «Бровари-молоко» & 0,21 & 0,2 & 0,16 & 0,13 & 1,31 & 1,18 & 0,78 & 0,64 \\
\hline
\end{tabular}

3 наведених у табл. 9 даних видно, що рентабельність продажу п'яти підприємств коливається у межах $1 \%-24 \%$. Найвищий рівень рентабельності продажу протягом 2013-2016 рр. зафіксовано у ТДВ «Бровари-молоко». Найнижчі показники у ПАТ «Кременчуцький міськмолокозавод».

Аналіз рентабельності використання власного капіталу показує, що інвестор може очікувати отримати від 4\% до $81 \%$ на вкладений капітал. Слід звернути увагу на ПАТ «Нововодолазький молокозавод», у якого зафіксовано збиткову діяльність. Проте від'ємний результат отриманий цим підприємством не через фінансові збитки за результатом 2016 р., а через від’ємне значення власного капіталу. Це відбулося внаслідок наявності у структурі даного підприємства нерозподіленого збитку минулого року.

\section{Висновки}

Слід зазначити, що виокремлення категорій «результативність» і «ефективність» та чітке їхнє розуміння $є$ дуже важливим для успішного функціонування підприємств. Проведений аналіз ефективності показав, що фактично всі підприємства нашої вибірки мають значення $d$-коефіцієнта менше за одиницю. Така ситуація свідчить про певну нераціональність сформованих моделей розвитку з позицій донесення вартості молочної продукції до iï кінцевих споживачів. Відомо, що ефект будь-якої системи управління $є$ за 
своєю природою синергетичним, тобто ефектом посилення взаємодії і координації між елементами цієї системи. Об’єктивною основою виникнення синергетичного ефекту системи є реальна взаємодія іiі елементів. Тому слід відмітити, що запропонована в дослідженні методика оцінки результативності потребує удосконалення, оскільки вона не дає загальну оцінку, а тільки характеризує кожен показник окремо. Це лише перший етап методики управління результативністю підприємств.

\section{Література}

1. Тищенко А.Н. Оценка действенности функционирования организации в условиях рынка / А.Н. Тищенко, Я.О. Светличная // Економіка транспортного комплексу — 2001. № 4. - C. 147-152.

2. Олексюк O.I. Економіка результативності діяльності підприємства: монографія / О.І. Олексюк - Київ : КНЕУ, 2008. - 362 с.

3. Синк Д.С. Управление производительностью: планирование, измерение и оценка, контроль и повышение :пер. с анг. / Д. С. Синк. - Москва : Прогресс, 1989. - 528 с.

4. Полішук Н.В. Результативність діяльності суб'єктів господарювання: сутність, оцінка, основи регулювання: монографія / Н.В. Поліщук. - Київ : ВЦ НТЕУ, 2005. — 252 с.

5. Пєтухова O.M. Формування системи управління інноваційною діяльністю підприємств / О.М. Пєтухова // Наукові праці Національного університету харчових технологій. - 2012. - № $43-$ С. $174-179$.

6. Олексюк O.I. Споживач як ключовий суб'єкт в управлінні результативністю підприємства / О.І. Олексюк // Агросвіт. - 2009. - № 4. - С. 35-41.

7. Saltmarshe $D$. The performance framework: a systems approach to understanding performance management / D. Saltmarshe, M. Ireland, J. McGregor // Public Administration \& Development. — 2003. - Vol. 23, \# 5. - P. 445-456.

8. Гордієнко B.M. Система стратегічного управління витратами: концептуальні засади побудови / В.М. Гордієнко // Стратегія економічного розвитку України — 2012. — № 31. C. $111-216$. 